\title{
ANALISIS KESULITAN BELAJAR PADA MATA PELAJARAN SOSIOLOGI SISWA DI MAS MINHAJUL AMILIN
}

\author{
Lis Afrianti, Rustiyarso, Izhar Salim \\ Program Studi Pendidikan Sosiologi FKIP Untan Pontianak \\ Email: lisafrianti006@gmail.com
}

\begin{abstract}
This research goals to know the students' learning difficulties in class XI on subjects sociology seen from internal factors, external factors and the efforts of teachers to overcome the problem of learning difficulties. The approach used qualitative approach with descriptive methods. This study uses 5 informants. The results showed students' learning difficulties from internal factors of observations and interviews to students note that the students showed the causes of learning difficulties that come from within them, such as having an attitude of learning, motivation, concentrating poor. Less able to demonstrate learning achievement, lack of confidence and poor study habits. Of external factors, family and school environment, lack of supervision and attention from their parents as well as the lack of availability of supporting infrastructure in the learning process causing the child into learning difficulties. The efforts of teachers in overcoming learning difficulties already showed results. Seen from the value obtained by the students after the teacher did stage treatment can reach values minimum completeness (KKM).
\end{abstract}

\section{Keywords: Students' Difficulties of Studying, TeacherEffort, The Causes}

\section{PENDAHULUAN}

Pendidikan merupakan usaha dengan tujuan untuk mengembangkan kualitas manusia, maka dalam pelaksanaan hendaknya setiap jenis serta tingkatan pendidikan berada dalam proses berkesinambungan dan terhubung dalam sistem pendidikan yang integral. Pendidikan menjadi bagian penting dan tidak dapat dipisahkan dari bermasyarakat. Berkembangnya pengetahuan serta majunya teknologi diiringi tuntutan kehidupan bermasyarakat telah membawa konsekuensi bagi dunia pendidikan agar selalu melakukan berbagai upaya penyesuaian untuk mampu menyiapkan peserta didik yang mampu bersaing dan menghadapi berbagai tantangan kehidupan yang cukup kompleks. Manfaat lain dari pendidikan adalah manusia dapat berkembang secara fisik, mental, emosional, sosial, dan etika menuju ke arah yang lebih baik baik dari segi kematangan berfikir dan kedewasaan bersikap. Sekolah merupakan tempat kegiatan belajar mengajar berlangsung serta salah satu lembaga pendidikan formal. Sekolah akan menjadi sarana untuk dikembangkan ilmu pengetahuan dengan diajarkan langsung bagi peserta didik. Para guru dan siswa terlibat secara interaktif dalam proses pendidikan.

Belajar merupakan proses dari perkembangan hidup manusia. Karena itu belajar secara aktif dan integratif dengan menggunakan berbagai bentuk perbuatan untuk mencapai suatu tujuan. Salah satu parameter yang digunakan untuk mengukur tingkat pengetahuan, penguasaan dan keterampilan siswa terhadap mata pelajaran adalah prestasi belajar yang umumnya ditunjukkan dalam bentuk nilai. Namun pada kenyataannya yang terjadi dilapangan, prestasi belajar pada mata pelajaran sosiologi yang dicapai oleh siswa kelas XI di MAS Minjahul Amilin Kabupaten Kubu Raya belum optimal. Kegiatan belajar siswa tidak selalu berjalan 
dengan lancar, terlebih banyak hal pemicu munculnya kesulitan dalam belajar oleh siswa. Penyebab kesulitan belajar disebabkan siswa tidak mampu memahami ilmu yang telah diajarkan sehingga memicu ketidakpahaman terhadap suatu pelajaran. Ciri-ciri kesulitan dalam belajar akan tampak pada diri siswa yaitu saat siswa tidak berkonsentrasi dengan baik, siswa mendapat nilai yang rendah, dan siswa tidak menunjukkan keseriusan, serta sebagian besar peserta didik tidak paham pelajaran yang telah guru berikan. Inilah kenyataan paling sering dijumpai pada setiap peserta didik dalam kehidupan sehari-hari dalam kaitannya dengan kegiatan belajar mengajar.

Hal ini tentu diperlukan solusi pemecahan apabila dibiarkan akan membawa dampak besar terhadap rendahnya prestasi belajar yang diperoleh siswa dan akan menimbulkan tidak tercapainya tujuan pembelajaran. Oleh karena itu perlu adanya tindakan untuk mencari faktor penyebab kesulitan belajar siswa terhadap suatu mata pelajaran. Sehingga diperlukan adanya kerjasama yang baik antara guru, sekolah, orangtua, dan masyarakat serta siswa itu sendiri untuk bersama-sama mengatasi penyebab kesulitan belajar tersebut. Sehingga diharapkan sekolah dapat mencetak lulusan berkompeten serta mempunyai prestasi belajar yang bagus.

Syaiful Bahri Djamarah (2013) menyatakan bahwa kesulitan belajar merupakan suatu kondisi di mana siswa tidak dapat belajar secara wajar, disebabkan adanya gangguan, hambatan ataupun ancaman dalam belajar. Anak yang mengalami kesulitan belajar akan sulit untuk menyerap pelajaran, baik kesulitan itu datang dari dirinya sendiri, dari lingkungannya ataupun karena faktorfaktor lain yang menjadi pemicunya. Faktorfaktor yang dapat menyebabkan anak kesulitan belajar dibagi menjadi dua yaitu faktor internal dan faktor eksternal. Menurut Dimyati dan Mudjiono (2013) faktor internal yang dapat menyebabkan kesulitan belajar diantaranya karena faktor kesiapan dalam belajar, motivasi belajar, konsentrasi belajar, mengulang-ulang pelajaran, menyimpan perolehan hasil belajar, kemampuan prestasi atau unjuk hasil kerja, rasa percaya diri, inteligensi dan keberhasilan belajar, kebiasaan belajar, serta cita-cita siswa. Sedangkan faktor eksternal Haryu Islamudin (2012) menyatakan diantara faktornya karena pengaruh lingkungan keluarga dan lingkungan sekolah.

Berdasarkan observasi yang peneliti lakukan di kelas XI di MAS Minhajul Amilin, proses belajar mengajar mata pelajaran sosiologi terdapat beberapa orang siswa ngobrol dengan teman sebangku, dan sebagian siswa juga ada yang mengantuk. Pernyataan ini diperkuat dari informasi dengan guru pelajaran sosiologi. beliau menyatakan bahwa pada saat mengajar ada siswa ngobrol dengan teman sebangku dan sebagian siswa juga ada yang terlihat tidak fokus karena mengantuk.

Dari segi lokasi, MAS Minjahul Amilin berada di Desa Sungai Asam berada di pinggir jalan desa. Untuk tenaga pengajarnya sendiri, hanya ada 1 (satu) guru sosiologi yang mengajar seluruh siswa kelas X, XI dan XII.

Berdasarkan penjelasan di atas, maka yang menjadi penyebab kesulitan belajar yang dialami siswa kelas XI di MAS Minhajul Amilin khususnya pada mata pelajaran sosiologi dapat diduga berasal dari faktor internal dan faktor eksternal. Diduga beberapa faktor internal penyebab kesulitan belajar adalah sikap dalam belajar, motivasi dalam belajar, konsentrasi belajar, kemampuan meraih prestasi dan rasa percaya diri siswa serta kebiasaan belajar. Sedangkan faktor eksternal kesulitan belajar siswa yaitu dari lingkungan keluarga dan lingkungan sekolah.

Kenyataan ini didukung dengan nilai ratarata tahun ajaran 2018/2019 yang diperoleh siswa kelas XI MAS Minhajul Amilin pada mata pelajaran sosiologi. Berdasarkan survey data awal, berikut ini peneliti sajikan capaian belajar mata pelajaran sosiologi siswa kelas XI di MAS Minhajul Amilin Kabupaten Kubu Raya tahun ajaran 2018/2019. 
Tabel 1.Capaian Belajar Mata Pelajaran Sosiologi Kelas VII

\begin{tabular}{ccccc}
\hline No & Interval Nilai & Jumlah & $\%$ & Keterangan \\
\hline 1 & $<70$ & 17 & 66 & Tidak Tuntas \\
2 & $=70$ & 6 & 16 & Tuntas \\
3 & $>70$ & 7 & 18 & Tuntas (Diatas Margin) \\
\hline & $\sum$ & 30 & $100 \%$ & \\
\hline
\end{tabular}

Data di atas menunjukkan fakta kesulitan belajar siswa kelas XI MAS Minhajul Amilin Kabupaten Kubu Raya. Total siswa kelas XI MAS Minhajul Amilin sekitar 30 orang, dari 30 orang tersebut sekitar $66 \%$ atau 17 orang siswa tidak tuntas dengan nilai $<70$ sedangkan nilai $=70$ hanya berjumlah 6 orang siswa dan tuntas (diatas margin) $>70$ berjumlah 7 orang siswa.

Pemaparan yang dicantumkan diatas menjadi dasar pemikiran peneliti untuk meneliti "Analisis kesulitan belajar pada matapelajaran sosiologi siswa kelas XI di MAS Minhajul Amilin Kabupaten Kuburaya". Tujuan penelitian ini adalah untuk mengetahui bagaimana siswa mengalami kesulitan belajar dinilai melalui faktor internal dan eksternal serta upaya yang dilakukan oleh guru dalam mengatasi kesulitan belajar siswa kelas XI di MAS Minhajul Amilin Kabupaten Kubu Raya.

Manfaat penelitian ini secara teori diharapkan bermanfaat terutama untuk mengetahui faktor yang menjadi penyebab kesulitan belajar siswa yang dapat dikaji dari dua faktor yaitu faktor internal dan faktor eksternal. Bagi guru, dengan penelitian ini memberi sumbangan pemikiran bagi sekolah sebagai pertimbangan untuk dijadikan acuan dalam mengajar agar mampu mengatasi masalah-masalah kesulitan belajar siswa yang akhirnya dapat meningkatkan minat, motivasi serta hasil belajar siswa. Dan bagi pembaca, penelitian ini diharapkan dapat menjadi tambahan referensi bagi pembaca dan dapat digunakan sebagai bahan acuan dalam penelitian yang memiliki objek yang sama selanjutnya.

\section{METODE PENELITIAN}

Metode penelitian yang digunakan dalam penelitian ini adalah metode kualitatif deskriptif. Satori menyatakan (2011) "penelitian kualitatif merupakan pendekatan penelitian dalam menjawab permasalahan yang memerlukan pemahaman secara menyeluruh dan mendalam mengenai objek yang diteliti, untuk mendapatkan kesimpulan penelitian dalam waktu dan situasi yang bersangkutan". Sedangkan menurut Sugiyono (2013) "metode desktiptif merupakan suatu penelitian yang menggambarkan atau menjelaskan secara fakta, akurat serta sistematis mengenai sifat populasi tertentu". Berdasarkan dari pendapat kedua para ahli tersebut, maka yang menjadi alasan peneliti akan mendeskripsikan faktor penyebab kesulitan belajar siswa di MAS Minhajul Amilin sesuai dengan realita dan fakta yang ada.

Subyek dalam penelitian ini yaitu guru bidang studi sosiologi dan siswa sebagai informan yang mengalami kesulitan belajar. Sumber data dalam penelitian ini adalah sumber data primer dan sumber data sekunder. Sumber data primer diperoleh secara lansung melalui wawancara yang telah dilakukan antara peneliti dengan informan. Informan dalam penelitian ini adalah guru bidang studi sosiologi dan siswa yang mengalami kesulitan belajar di MAS Minhajul Amilin. Adapun sumber data sekunder diperoleh dari arsiparsip yang dimiliki oleh guru bidang studi sosiologi, yaitu tentang data dan arsip namanama siswa yang mengalami kesulitan belajar sosiologi di kelas XI MAS Minhajul Amilin Kabupaten Kubu Raya.

Pengumpulan data dalam penelitian ini menggunakan teknik observasi, teknik wawancara dan teknik studi dokumentasi. Dalam wawancara peneliti melakukan kontak langsung secara lisan dengan narasumber, dalam hal ini peneliti melakukan wawancara secara langsung kepada guru bidang studi 
sosiologi dan siswa yang mengalami kesulitan belajar sosiologi. Dalam observasi data yang dilakukan adalah mengamati secara langsung obyek yang akan diteliti yaitu bagaimana faktor penyebab kesulitan belajar siswa pada mata pelajaran sosiologi di MAS Minhajul Amilin Kabupaten Kubu Raya. Studi dokumentasi adalah pengumpulan data dengan mencari dan mempelajari data yang ada hubungannya dengan masalah yang diteliti.

Masalah yang diteliti dalam penelitian ini yaitu bagaimana siswa kelas XI MAS Minhajul Amilin mengalami kesulitan belajar siswa pada mata pelajaran sosiologi dan upaya guru mengatasi kesulitan belajar siswa. Jadi dalam hal ini, peneliti mengamati pada faktor penyebab kesulitan belajar siswa pada mata pelajaran sosiologi yang dilihat dari faktor internal, faktor eksternal siswa dan upaya yang dilakukan dalam menanggulangi siswa yang mengalami kesulitan belajar di MAS Minhajul Amilin. Teknik analisis data penelitian ini terdiri dari 3 tahap, yaitu reduksi data, penyajian data, verifikasi dan pengambilan keputusan, perpanjangan observasi dan triangulasi.

\section{HASIL PENELITIAN DAN PEMBAHASAN \\ Hasil}

Berisi hasil-hasil studi empiris atau teoritis yang ditulis secara sistematis, analisis kritis, dan informatif. Penggunaan tabel, gambar, dll. untuk mendukung hasil penelitian dan mendukung informasi penting, misalnya, hasil pengujian model, hasil uji statistik, dll. Argumentative

Secara historis berdirinya sekolah Madrasah Aliyah Minhajul Amilin didahului dengan didirikannya Madrasyah Diniyah Minhajul Amilin pada bulan Desember 1984 oleh bapak Muhammad Ainul Yakin. Sekolah didirikan dengan luas lahan sekitar 2 Hektar. Selanjutnya pada ditahun 2009 Madrasah Aliyah dibentuk dengan kepala Madrasah Aliyah Sunaryo, S.Pd.I. Jabatan kepala Madrasyah Aliyah Minhanjul Amilin hingga sekarang masih dijabat oleh Sunaryo, S.Pd.I
Informan terdiri dari 1 orang guru bidang studi sosiologi dan 4 orang siswa yang mengalami kesulitan belajar mata pelajaran sosiologi. Adapun siswa yang menjadi informan dalam penelitian ini yaitu siswa yang tercatat dari beberapa siswa dalam arsip yang dimiliki oleh guru bidang studi sosiologi. 4 orang siswa tersebut adalah siswa kelas XI MAS Minhajul Amilin.

Tabel 2.Data Identitas Informan

\begin{tabular}{ccc}
\hline No & Nama & Jabatan \\
\hline 1 & SS & Guru Sosiologi \\
\hline 2 & AJ & Siswa Kelas XI \\
\hline 3 & AZ & Siswa Kelas XI \\
\hline 4 & MR & Siswa Kelas XI \\
\hline 5 & FD & Siswa Kelas XI \\
\hline
\end{tabular}

Berdasarkan Tabel 2 menggambarkan data identitas informan dalam penelitian ini, diantaranya adalah Pak Sigit Setiawan S.Pd I selaku guru mata pelajaran sosiologi dan 2 orang siswa kelas XI yang mengalami kesulitan belajar mata pelajaran sosiologi. Adapun siswa yang menjadi informan dalam penelitian ini yaitu Aminatul Jannah, Aminatul Zahra, M.Rofiq dan Fajar Dwi merupakan siswa dari beberapa siswa yang sering mendapatkan nilai rendah pada mata pelajaran sosiologi.

Pada bagian observasi peneliti melakukan pengamatan secara mendalam tentang keadaan yang terjadi di lokasi penelitian secara langsung yang dituangkan dalam bentuk temuan-temuan. Observasi tersebut dilakukan oleh peneliti sebanyak 3 kali dimulai pada tanggal 23, 24, dan 27 Juli 2019. Hal ini dilakukan peneliti setelah melewati berbagai tahap pendekatan, persetujuan, dan persiapan dalam pelaksanaannya. Selain itu, peneliti juga menyaring dan menyajikan data supaya tidak melenceng dari fokus penelitian dan sasaran utama dalam skripsi ini yaitu tentang "Analisis kesulitan belajar pada matapelajaran sosiologi siswa kelas XI di MAS Minhajul Amilin Kabupaten Kuburaya”.

Adapun faktor kesulitan belajar siswa dapat dilihat dari faktor internal dan faktor eksternal. Faktor internal tersebut yakni sikap 
dalam belajar, motivasi dalam belajar, konsentrasi belajar, kemampuan berprestasi, rasa percaya diri, dan kebiasaan dalam belajar. Sedangkan faktor eksternal yakni berasal dari lingkungan keluarga dan lingkungan sekolah. Selanjutnya kesulitan belajar yang dialami oleh siswa ini tentunya harus di atasi oleh guru yang bersangkutan melalui 6 tahap yakni pengumpulan data, pengolahan data, diagnosis, prognosis, treatment, dan evaluasi.

Dari hasil observasi pertama sampai observasi ke tiga yaitu pada tanggal 23 Juli 2019, 24 Juli 2019dan 27 Juli 2019 mulai dari pukul 13.00, ditemukan pada faktor internal saat proses pembelajaran sosiologi berlangsung. Peneliti menemukan beberapa orang siswa menunjukkan sikap mengabaikan kesempatan dalam belajar. Sikap tersebut terlihat ketika mengikuti proses pembelajaran masih banyak siswa yang tidak memperhatikan penjelasan guru dengan baik, bersikap acuh dan tidak serius mengikuti proses belajar mengajar.

Selain itu motivasi siswa dalam belajar terlihat masih kurang, hal ini dapat dilihat dari sikap yang di tunjukkan siswa yang kurang mampu bertahan untuk belajar lebih lama, cepat bosan serta kurang sungguh-sungguh di dalam mengerjakan tugas yang diberikan oleh guru. Selain itu, siswa juga tidak bisa berkonsentrasi dengan baik pada saat proses pembelajaran berlansung. Hal ini disebabkan oleh beberapa hal diantaranya cuaca yang panas disertai dengan tidak tersedianya kipas angin di dalam kelas, dan suasana kelas yang ribut. Cara guru menjelaskan materi yang terlalu monoton juga menyebabkan siswa menjadi bosan dan mengantuk saat mengikuti proses pembelajaran. Siswa yang mengalami kesulitan belajar bukan berarti tidak memiliki kemampuan berprestasi dan menunjukkan hasil kerja mereka. Ada beberapa orang yang memiliki kemampuan berbrestasi dan dapat menunjukkan hasil kerja mereka. Namun ada beberapa siswa lainnya yang belum menunjukkan kemampuan berprestasi dan unjuk hasil kerja mereka.

Siswa yang belum bisa menunjukkan hasil kerja dikarenakan kurangnya rasa percaya diri, mereka takut jika pendapat atau jawaban yang mereka ajukan tidak tepat. Namun sebaliknya, siswa yang memiliki kemampuan berprestasi dan mampu menunjukkan hasil kerja biasanya memiliki rasa percaya diri di dalam dirinya. Dari observasi yang dilakukan peneliti menemukan ada beberapa orang siswa yang sudah menunjukkan rasa percaya diri mereka. Terlihat ketika mereka berani menjawab dan mengajukan pertanyaan kepada guru sosiologi. Namun siswa yang mengalami kesulitan belajar ini masih memiliki kebiasaan belajar yang kurang baik. Masih ada siswa yang mencontek pekerjaan teman saat mengerjakan tugas evaluasi yang diberikan oleh guru di akhir pembelajaran dan belajar ketika akan ada ulangan dan mereka tidak pernah mengulang pelajaran yang sudah mereka dapatkan disekolah saat dirumah. Selain itu siswa juga hanya memiliki sedikit ringkasan materi dan catatan penting. Tidak ada usaha dari diri siswa untuk memperkaya materi dengan cara mencari buku tambahan di perpustakaan maupun di internet.

Selanjutnya dari faktor eksternal penyebab kesulitan belajar yakni dapat berasal dari lingkungan keluarga dan lingkungan sekolah. Pada saat observasi, peneliti tidak menemukan adanya faktor yang berasal dari lingkungan keluarga. Namun di lingkungan sekolah peneliti menemukan adanya beberapa faktor yang dapat menyebabkan siswa mengalami kesulitan belajar, diantaranya seperti ketersediaan sarana dan prasarana yang masih belum lengkap. Seperti tidak tersedianya media pembelajaran berupa infokus, ketersediaan buku-buku di perpustakaan yang tidak lengkap, tidak adanya kipas angin yang menyebabkan siswa kepanasan ketika cuaca sedang panas yang pada akhirnya membuat siswa tidak bisa berkonsentrasi saat mengikuti proses pembelajaran.

Selain itu teman sebaya tentunya juga memberikan pengaruh dalam proses belajar siswa di sekolah. Tidak sedikit siswa yang sebelumnya rajin pergi kesekolah, aktif mengikuti kegiatan-kegiatan sekolah kemudian berubah menjadi siswa yang malas, tidak disiplin dan menunjukkan prilaku buruk 
dalam belajar. Hal-hal seperti ini dapat menjadi faktor yang menimbulkan masalah kesulitan pada siswa dalam belajar. Pada sisi lain, lingkungan sekolah tentu saja dapat memeberikan pengaruh yang positif bagi siswa. Tidak sedikit siswa yang mengalami peningkatan hasil belajar karena pengaruh teman sebaya yang mampu memberikan motivasi kepadanya untuk belajar. Demikian pula banyak siswa yang mengalami perubahan sikap karena teman-teman sekolah memiliki sikap positif yang dapat dia tiru dalam pergaulan atau interaksi sehari-hari.

Pada saat observasi, peneliti tidak menemukan adanya upaya guru dalam mengatasi kesulitan belajar yang dialami siswa. Guru tidak melakukan beberapa langkah dalam upaya mengatasi kesulitan belajar yakni pengumpulan data, pengolahan data, diagnosis, prognosis, treatment dan evaluasi pada saat proses pembelajaran berlangsung.

\section{Pembahasan}

Berdasarkan hasil observasi dan wawancara peneliti terhadap siswa yang mengalami kesulitan belajar di kelas XI MAS Minhajul Amilin peneliti menemukan adanya faktor internal yang menyebabkan siswa mengalami kesulitan belajar dari. Peneliti menemukan ada beberapa orang siswa yang terlihat menunjukkan adanya masalah dalam belajar di dalam dirinya yang ditunjukkan melalui sikap belajar yang kurang baik seperti acuh terhadap penjelasan guru, tidak tahan belajar lama, bosan, pasif, mengantuk, dan lain-lainnya. Hal ini seperti yang dituturkan oleh siswa bahwa "pelajaran sosiologi membosankan sehingga membuat saya mengantuk"

Dalam kegiatan belajar, motivasi individu biasanya didapatkan dalam bentuk kesungguhan, ketekunan belajar dalam menyimak pelajaran dan kerajinan dalam mengerjakan tugas. Namun, hal ini tidak terjadi pada siswa yang mengalami kesulitan belajar di kelas XI, siswa terlihat tidak bisa bertahan untuk belajar lebih lama, kurang bersungguh-sungguh menyimak isi pelajaran, bosan dan kurang sungguh-sungguh di dalam mengerjakan tugas.

Selanjutnya siswa menunjukkan sikap kurang berkonsentrasi dalam belajar. Hal ini terlihat saat ada beberapa siswa yang sibuk dengan kegiatan mereka sendiri, ada yang mengobrol dengan teman di sampingnya, ada yang menggambar, ada yang bermain HP, ada yang terlihat mengantuk bahkan ada yang sampai tertidur di dalam kelas pada saat guru sedang menyampaikan materi di depan kelas. Sulitnya siswa untuk berkonsentrasi dengan baik juga dapat disebabkan oleh cuaca yang panas dan tidak adanya ketersediaan kipas angin di dalam kelas. Banyak siswa yang menjadikan buku sebagai alat untuk berkipas pada saat belajar yang tentu saja dapat mengganggu konsentrasi mereka dalam menerima pelajaran. Siswa menuturkan "kadang saya konsentrasi kadang juga tidak bisa berkonsentrasi apalagi jika teman-teman dikelas ribut ataupun sibuk dengan urusan mereka masing-masing ada yang tidur, ngobrol dan main hp tentu saja membuat saya tidak berkonsentrasi. Biasanya kalau lagi panas seperti hari ini juga sulit untuk berkonsentrasi dalam belajar".

Selain itu siswa juga belum mampu menunjukkan hasil kerja dan kemampuan berprestasi mereka. Siswa belum bisa untuk membuktikan keberhasilan dalam belajar. Hal ini ditemukan peneliti pada saat guru bertanya kepada siswa mengenai materi yang telah dibahas, kadang hanya ada satu orang siswa yang bisa menjawab bahkan kadang-kadang tidak ada sama sekali siswa yang menjawab pertanyaan yang diberikan oleh guru. Tidak adanya rasa percaya diri membuat siswa tidak bisa menunjukkan kemampuan yang ada pada diri mereka. Rasa percaya diri siswa yang mengalami kesulitan belajar ini juga masih sangat kurang. Masih banyak siswa yang belum berani mengungkapkan pendapat mereka dan takut salah untuk mengajukan pendapat mereka di depan teman- temannya.

Kebiasaan belajar terbentuk karena tingkah laku berulang-ulang sepanjang hidup individu dan biasanya mengikuti cara tertentu, sehingga menciptakan kebiasaan belajar yaitu cara-cara belajar yang paling sering dilakukan 
oleh siswa dengan cara Berdasarkan paparan penjelasan di atas dapat disimpulkan bahwa kesulitan belajar siswa kelas XI pada mata pelajaran sosiologi di MAS Minhajul Amilin dilihat dari faktor internal sudah sesuai dengan teori yang dikemukakan oleh Syaiful Bahri Djamarah (2013). Hal ini ditemukan pada hasil observasi dan wawancara kepada siswa yang mana dapat diketahui siswa menunjukkan adanya faktor penyebab kesulitan belajar yang berasal dari dalam diri mereka sendiri. serta kebiasaan belajar terbentuk aktifitas belajar, baik secara sengaja ataupun tidak sengaja.

Pada faktor eksternal, di dalam lingkungan keluarga, sudah seharusnya orang tua memberikan dorongan, dukungan, semangat dan motivasi kepada anak agar bersungguh-sungguh dalam belajar. Selain memberikan motivasi dan dukungan kepada anak agar bersungguh- sungguh dalam belajar, orang tua juga harus memberikan pengawasan, mengontrol dan memperhatikan kemajuan anak dalam belajar di sekolah. Namun kenyataannya masih banyak orang tua yang tidak memberikan pengawasan, kurang mengontrol belajar anak dan kurang memberikan perhatian terhadap kemajuan belajar anaknya di sekolah.

Sebagai makhluk sosial, setiap siswa tidak akan mungkin melepaskan dirinya dari interaksi dengan orang-orang di lingkungan sekolah, terutama sekali dengan teman-teman sebaya, guru-guru dan staf sekolah. Dalam kajian sosiologis, sekolah merupakan sistem sosial di mana setiap orang yang ada di dalamnya terikat norma-norma dan aturanaturan sekolah yang disepakati sebagai pedoman untuk mewujudkan ketertiban pada lembaga pendidikan tersebut. Disamping aturan formal sekolah, para siswa biasanya juga memiliki norma-norma dan aturan-aturan yang lebih spesifik sebagai suatu consensus bersama untuk ditaati oleh anggota kelompok masing-masing.

Di dalam lingkungan sekolah selain dapat memberikan dampak positif namun juga memberikan beberapa dampak negatif terhadap siswa terutama dari teman-teman sebaya mereka. Tidak sedikit siswa yang sebelumnya rajin pergi kesekolah, aktif mengikuti kegiatan-kegiatan sekolah kemudian berubah menjadi siswa yang malas, tidak disiplin dan menunjukkan perilaku buruk dalam belajar. Hal-hal seperti ini dapat menjadi faktor yang menimbulkan masalah kesulitan pada siswa dalam belajar.

Dinilai dari lingkungan sekolah tentu saja dapat memberikan pengaruh yang positif bagi siswa. Siswa mudah termotivas dalam belajar diakibatkan pengaruh dari teman. Demikian pula dengan perilaku sikap positif dapat ditiru dalam interaksi dan pergaulan dengan teman sebaya dalam kegiatan seharihari.

Faktor lain yang memberikan dampak hasil belajar adalah tersedianya sarana dan prasarana sekolah. Kondisi bangunan sekolah dan ruang kelas yang baik, ruang perpustakaan sekolah yang tersedia, fasilitas kelas dan laboratorium memenuhi, adanya buku-buku pelajaran, serta media pembelajaran merupakan komponen penting yang dapat mendukung terwujudnya kegiata belajar siswa. dari dimensi guru, ketersediaan fasilitas penunjang pembelajaran akan memberikan kemudahan dalam melaksanakan kegiatan pembelajaran.

Namun sebaliknya, apabila dibandingkan dengan keadaan bangunan sekolah dan ruang kelas yang tidak tertata dengan baik, sumber-sumber belajar sangat terbatas, kurangnya referensi di perpustakaan sekolah, kurangnya buku pelajaran, tidak tersedia media pembelajaran, semuanya ini tentu akan berdampak terhadap pembelajaran serta motivasi belajar siswa. Oleh karena itu fasilitas menjadi bagian terpenting dalam upaya mendukung terwujudnya proses pembelajaran yang diinginkan.

Berdasarkan penjelasan diatas disimpulkan bahwa kesulitan belajar siswa di pelajaran sosiologi dinilai dari faktor eksernal seperti lingkungan keluarga dan lingkungan sekolah sangat mempengaruhi hasil belajar siswa. Haryu Islamuddin (2012) menyatakan faktor eksternal dari kesulitan belajar pada siswa, berupa seluruh situasi dan kondisi lingkungan yang tidak mendukung aktivitas belajar siswa". Hal ini ditunjukkan pada 
perhatian orang tua siswa yang kurang dalam mengontrol kemajuan belajar anak serta minimnya sarana dan prasarana pendukung proses pembelajaran yang menyebabkan anak menjadi kesulitan di dalam belajar.

\section{SIMPULAN DAN SARAN Simpulan}

Berdasarkan data hasil dan pembahasan dalam penelitian ini maka dapat ditarik kesimpulan bahwa faktor penyebab kesulitan belajar siswa pada mata pelajaran sosiologi di MAS Minhajul Amilin disebabkan oleh faktor internal dan faktor eksternal siswa. Hal ini dapat terlihat dari hasil observasi dan wawancara. Kemudian kesimpulan yang dapat ditarik dari penelitian ini adalah sebagai berikut : (1) Kesulitan belajar siswa kelas XI pada mata pelajaran sosiologi di MAS Minhajul Amilin dilihat dari faktor internal terlihat dari hasil observasi dan wawancara kepada siswa yang mana dapat diketahui bahwa siswa menunjukkan adanya faktorfaktor penyebab kesulitan belajar yang berasal dari dalam diri mereka sendiri, seperti memiliki sikap belajar yang kurang baik, motivasi belajar yang rendah, sulit berkonsentrasi dalam belajar, kurang mampu menunjukkan prestasi belajar dan unjuk hasil kerja, kurang percaya diri dan kebiasaan belajar yang kurang baik. (2) Kesulitan belajar siswa pada mata pelajaran sosiologi di MAS Minhajul Amilin dilihat dari faktor eksternal seperti lingkungan keluarga dan lingkungan sekolah sangat mempengaruhi hasil belajar siswa.

Hal ini terlihat dari kurangnya pengawasan dan kurangnya perhatian orang tua dalam mengontrol kemajuan belajar anak di sekolah serta kurangnya ketersediaan sarana dan prasarana pendukung dalam proses pembelajaran yang menyebabkan anak menjadi kesulitan di dalam belajar. (3) Upaya yang dilakukan oleh guru dalam mengatasi masalah kesulitan belajar dapat terlihat dari tahap-tahap yang dilakukan dalam upaya mengatasi masalah kesulitan belajar siswa mulai dari tahap yang pertama yaitu tahap pengumpulan data sampai tahap yang terakhir yaitu evaluasi. Upaya guru dalam mengatasi kesulitan belajar tersebut juga sudah menunjukkan adanya hasil. Dapat dilihat dari nilai yang diperoleh siswa setelah guru melakukan tahap treatment/perlakuan, dimana siswa-siswa yang mengalami kesulitan belajar ini sudah bisa mencapai nilai ketuntasan minimal (KKM).

\section{Saran}

Berdasarkan hasil penelitian yang diperoleh serta pembahasan tentang hasil tersebut, maka peneliti memberikan saransaran sebagai berikut: (1) Kepada siswa yang mengalami kesulitan belajar, agar siswa lebih bersungguh-sungguh dalam belajar dan jangan menyia-nyiakan kesempatan belajar sehingga nantinya dapat berhasil dalam belajar dan mendapatkan prestasi di sekolah. Jika hal ini dapat terwujud tentunya pihak sekolah dan keluarga akan merasa sangat bangga dengan prestasi yang didapat oleh siswa. (2) Faktor penyebab kesulitan belajar yang berasal dari faktor eksternal siswa, agar pihak keluarga dan pihak sekolah untuk samasama ikut mendukung kemajuan dalam belajar siswa. Dari pihak keluarga haruslah selalu memberikan dukungan, semangat dan motivasi agar anak bersungguh-sungguh dalam belajar dibarengi dengan memberikan pengawasan dan memberikan perhatian dalam mengontrol kemajuan anak di sekolah. Disamping itu kepada pihak sekolah peneliti menyarankan untuk memperhatikan sarana dan prasarana penunjang kemajuan belajar siswa. (3) Upaya guru dalam mengatasi kesulitan belajar yang dialami siswa pada mata pelajaran sosiologi di MAS Minhajul Amilin, agar guru sosiologi melakukan upayaupaya untuk mengatasi kesulitan belajar siswa melalui beberapa tahap. Khususnya pada tahap evaluasi, agar guru melakukan pembinaan yang bersifat remedial dengan membahas pokok-pokok bahasan yang dianggap sulit oleh siswa sampai siswa benarbenar memahami pokok bahasan tersebut dan mencapai nilai ketuntasan minimal (KKM).

\section{DAFTAR RUJUKAN}

Ahmadi, A., Supriyono, W. (2008). Psikologi Belajar. Jakarta: PT Rineka Cipta 
Aunurrahman. (2010). Belajar dan Pembelajaran. Bandung: Alfabeta.

Dimyati. M. (2013). Belajar dan Pembelajaran. Jakarta: Rineka Cipta.

Djamarah, Bahri S. 2013. Psikologi Belajar. Jakarta: Rineka Cipta

Hasibuan. M. (2006). Proses Belajar Mengajar. Bandung: PT Remaja Rosdakarya.

Islamuddin, H. (2012). Psikologi Pendidikan. Yogyakarta: Pustaka Pelajar.

Jamaris, M. (2014). Kesulitan Belajar (Perspektif, Assesmen dan Penanggulangannya Bagi Anak Usia Dini dan Usia Sekolah). Bogor: Ghalia Indonesia.

Nawawi, H. (2005). Metode Penelitian Bidang Sosial. Yogyakarta: Gajahmada University Press.
Nasution. (2008). Azas- Azas Kurikulum. Bandung: Jammars

Prayitno. (2009). Dasar Teori dan Praktis Pendidikan. Jakarta: PT Grasindo

Satori, D.,Komariah, A. (2011). Metodologi Penelitian Kualitatif. Bandung: Alfabeta.

Sugiyono. (2013). Metode Penelitian Pendidikan. Bandung : Alfabeta

Sutikno, M,S. (2013). Belajar dan Pembelajaran. Lombok: Holistica

Syah, M. (2012). Psikologi Belajar. Bandung: Rajawali Pres

Vetty Aprianty. (2016). Deskripsi Kesulitan Belajar Siswa pada Sub Materi Invertebrata Kelas X MIPA 2 MAN 2 Pontianak. Skripsi. Pontianak: FKIP UNTAN. 